\title{
Malignancy of the nail apparatus - clinical and dermoscopic analysis
}

\section{Nowotwory złośliwe aparatu paznokciowego - analiza kliniczna i dermoskopowa}

Alicja Romaszkiewicz', Martyna Sławińska', Wojciech Biernat², Kamil Drucis³, Roman J. Nowicki', Michał Sobjanek'

'Department of Dermatology, Venereology and Allergology, Medical University of Gdańsk, Poland

2Department of Pathomorphology, Medical University of Gdańsk, Poland

${ }^{3}$ Department of Surgical Oncology, Medical University of Gdańsk, Poland

'Katedra i Klinika Dermatologii, Wenerologii i Alergologii Gdańskiego Uniwersytetu Medycznego, Polska

${ }^{2}$ Katedra i Zakład Patomorfologii Gdańskiego Uniwersytetu Medycznego, Polska

${ }^{3}$ Katedra i Klinika Chirurgii Onkologicznej Gdańskiego Uniwersytetu Medycznego, Polska

Dermatol Rev/Przegl Dermatol 2018, 105, 593-603

DOI: https://doi.org/l0.5। |4/dr.2018.79|7|

\section{CORRESPONDING AUTHOR/ ADRES DO KORESPONDENCJI: dr hab. n. med. Michał Sobjanek Katedra i Klinika Dermatologii, Wenerologii i Alergologii Gdański Uniwersytet Medyczny ul. Kliniczna 1 a \\ 80-408 Gdańsk \\ tel. +48583492580 \\ e-mail: msobjanek@gumed.edu.pl}

\begin{abstract}
Introduction. Malignant neoplasms of the nail apparatus are rare tumours, often diagnosed with delay, which influences the further course. Dermoscopy improves the clinical differentiation of benign and malignant conditions of the nail apparatus, patients' follow-up and determination of the margins during surgical intervention (intraoperative onychoscopy). Herein we present another series of Polish patients with malignant tumours of the nail apparatus analysed with dermoscopy.
\end{abstract}

Objective. Epidemiological, clinical and dermoscopic analysis of patients with nail apparatus melanoma and nail apparatus squamous cell carcinoma.

Material and methods. We retrospectively analysed clinical data of 840 patients diagnosed and treated surgically at the Department of Dermatology, Venerology and Allergology, Medical University of Gdańsk (Poland) between January 2015 and November 2017. Three cases of nail apparatus melanoma and 4 cases of nail apparatus squamous cell carcinoma were identified and included in further detailed analysis. In all cases clinical diagnosis was confirmed histopathologically. Dermoscopy was available in 5 cases.

Results. Nail apparatus melanoma represented $8.3 \%$ of all diagnosed melanomas and nail apparatus squamous cell carcinoma $9.2 \%$ of all squamous cell carcinomas in the analysed period of time.

Conclusions. According to our material, nail apparatus malignancy is not uncommon. Dermoscopy supports the clinical differentiation between benign and malignant disorders of the nail apparatus, but should always be interpreted in association with medical history and physical examination. Histopathological examination remains the gold standard in the diagnosis of malignant tumours of the nail unit.

\section{STRESZCZENIE}

Wprowadzenie. Nowotwory złośliwe aparatu paznokciowego występują stosunkowo rzadko. Wiąże się to często z opóźnionym rozpozna- 
niem, które wpływa na rokowanie pacjentów. Dermoskopia aparatu paznokciowego (onychoskopia) jest przydatnym narzędziem w klinicznej diagnostyce różnicowej schorzeń aparatu paznokciowego i obserwacji pacjentów po zakończonym leczeniu. Onychoskopia śródoperacyjna jest z kolei pomocna przy określaniu zakresu leczenia chirurgicznego. W pracy przedstawiono analizę 7 przypadków pacjentów ze złośliwymi guzami aparatu paznokciowego z uwzględnieniem obrazów dermoskopowych.

Cel pracy. Analiza danych epidemiologicznych i klinicznych oraz obrazów dermoskopowych u pacjentów z czerniakiem oraz rakiem kolczystokomórkowym aparatu paznokciowego.

Materiał i metodyka. Retrospektywnie przeanalizowano dane kliniczne 840 pacjentów diagnozowanych i leczonych chirurgicznie w Klinice Dermatologii, Wenerologii i Alergologii Gdańskiego Uniwersytetu Medycznego od stycznia 2015 do listopada 2017 roku. W analizowanym materiale zidentyfikowano 3 przypadki czerniaka aparatu paznokciowego i 4 przypadki raka kolczystokomórkowego aparatu paznokciowego, które poddano dalszej szczegółowej analizie. We wszystkich przypadkach rozpoznanie było potwierdzone histopatologicznie. Obraz dermoskopowy był dostępny w 5 przypadkach.

Wyniki. W analizowanym okresie czerniaki aparatu paznokciowego stanowiły $8,3 \%$ wszystkich rozpoznanych czerniaków. Dla raka kolczystokomórkowego aparatu paznokciowego odsetek ten wyniósł 9,2\%.

Wnioski. Przedstawiony materiał wskazuje, że nowotwory złośliwe aparatu paznokciowego nie są rzadkością. Badanie dermoskopowe jest pomocne w klinicznej diagnostyce różnicowej złośliwych i łagodnych zmian w obrębie aparatu paznokciowego, jednak jego wynik powinien być interpretowany $\mathrm{w}$ zestawieniu $\mathrm{z}$ danymi $\mathrm{z}$ wywiadu oraz badania przedmiotowego. Złotym standardem w diagnostyce złośliwych nowotworów aparatu paznokciowego pozostaje badanie histopatologiczne.

Key words: nail apparatus, neoplasms, melanoma, squamous cell carcinoma, dermoscopy.

Słowa kluczowe: aparat paznokciowy, nowotwory, czerniak, rak kolczystokomórkowy, dermoskopia.

\section{INTRODUCTION}

Malignant neoplasms of the nail apparatus are rare tumours, often diagnosed with delay, which may also influence the prognosis. The most common are melanoma (nail apparatus melanoma NAM) and squamous cell carcinoma (nail apparatus squamous cell carcinoma - NASCC). The role of dermoscopy of the nail apparatus (onychoscopy) is constantly increasing. It improves the clinical differentiation of benign and malignant conditions of the nail apparatus, patients' follow-up and defining the margins during surgical intervention (intraoperative onychoscopy). Herein we present another series of 7 Polish patients with malignant tumours of nail apparatus assessed with dermoscopy.

\section{WPROWADZENIE}

Nowotwory złośliwe aparatu paznokciowego występują stosunkowo rzadko. Są one późno rozpoznawane, co z kolei negatywnie wpływa na rokowanie. Do najczęstszych nowotworów złośliwych w tej lokalizacji należą: czerniak aparatu paznokciowego (nail apparatus melanoma - NAM) oraz rak kolczystokomórkowy aparatu paznokciowego (nail apparatus squamous cell carcinoma - NASCC). Rola dermoskopii aparatu paznokciowego (onychoskopii) jest obecnie przedmiotem badań. Metoda ta ma zastosowanie w diagnostyce różnicowej zmian złośliwych i łagodnych, jak również w obserwacji pacjentów po zakończonym leczeniu oraz określaniu zasięgu interwencji chirurgicznej (onychoskopia śródoperacyjna). W pracy przedstawiono analizę 7 przypadków pacjentów ze złośliwymi 


\section{OBJECTIVE}

The aim of the study was epidemiological, clinical and dermoscopic analysis of 3 patients with NAM and 4 patients with NASCC.

\section{MATERIAL AND METHODS}

We retrospectively analysed clinical data of 840 patients diagnosed and treated surgically at the Department of Dermatology, Venereology and Allergology, Medical University of Gdańsk (Poland) between January 2015 and November 2017. There were 36 cases of melanoma and 49 cases of squamous cell carcinoma in the studied period of time. Three cases of NAM and 4 cases of NASCC were identified and included in further detailed analysis. In all cases the clinical diagnosis was confirmed histopathologically. Dermoscopy was available in 5 cases.

Nail apparatus melanoma was recognised based on histopathological results of excisional biopsy and patients were treated surgically. Nail apparatus squamous cell carcinoma was recognised based on histopathological evaluation of incisional biopsy. In one case due to the infiltration of the bone, amputation of the distal phalanx was performed. Two patients were treated surgically (total excision of nail apparatus and skin graft). One patient was treated with topical 5-fluorouracil.

\section{RESULTS}

Nail apparatus melanoma represented $8.3 \%$ of all diagnosed melanomas and NASCC $9.2 \%$ of all squamous cell carcinomas in the analysed period of time. Clinical characteristics of the patients are presented in table 1, as well as on the figures 1-7. There was no evidence of local or distant metastases in the studied group in the follow-up period (6-27 months).

\section{DISCUSSION}

Malignant tumours of the nail apparatus are rare, which influences the delay in diagnosis and subsequent patient prognosis [1]. The most common are NAM and NASCC. The previous Polish study by Sobjanek et al. shows that NAM and NASCC constitute $6.2 \%$ and $2.3 \%$ of nail tumours, respectively [2]. The same author in 2012 analysed nail apparatus alterations in a paediatric population $(n=82)$ and found no malignant tumours [3]. Despite the reported rarity of childhood nail apparatus neoplasia in Caucasian populations, in 2017 in our department guzami aparatu paznokciowego wraz z wynikami badania dermoskopowego.

\section{CEL PRACY}

Celem pracy była analiza danych epidemiologicznych i klinicznych oraz obrazów dermoskopowych u 3 pacjentów z NAM oraz 4 pacjentów z NASCC.

\section{MATERIA I METODYKA}

Retrospektywnie przeanalizowano dane kliniczne 840 pacjentów diagnozowanych i leczonych chirurgicznie w Klinice Dermatologii, Wenerologii i Alergologii Gdańskiego Uniwersytetu Medycznego od stycznia 2015 do listopada 2017 roku. W badanym okresie rozpoznano 36 przypadków czerniaka i 49 przypadków raka kolczystokomórkowego. Wśród tych nowotworów zidentyfikowano 3 przypadki NAM i 4 przypadki NASCC, które poddano dalszej szczegółowej analizie. U wszystkich pacjentów rozpoznanie było potwierdzone histopatologicznie. Badanie dermoskopowe wykonano w 5 przypadkach.

Czerniaka aparatu paznokciowego rozpoznawano na podstawie wyników badania histopatologicznego materiału pobranego podczas biopsji wycinającej. Pacjenci byli leczeni operacyjnie. Raka kolczystokomórkowego aparatu paznokciowego stwierdzono na podstawie oceny histopatologicznej fragmentu guza uzyskanego metodą biopsji incizjonalnej. $W$ jednym przypadku z powodu nacieku kości przeprowadzono amputację palca na poziomie paliczka dystalnego. Dwóch pacjentów leczono chirurgicznie (całkowite usunięcie aparatu paznokciowego i przeszczep skóry). U jednego pacjenta zastosowano leczenie miejscowe 5-fluorouracylem.

\section{WYNIKI}

W analizowanym okresie NAM stanowił 8,3\% wszystkich rozpoznanych czerniaków, a NASCC 9,2\% wszystkich raków kolczystokomórkowych. Charakterystykę kliniczną pacjentów przedstawiono w tabeli 1 oraz na rycinach $1-7$. W czasie obserwacji (627 miesięcy) w badanej grupie nie stwierdzono przerzutów miejscowych ani odległych.

\section{OMÓWIENIE}

Złośliwe nowotwory aparatu paznokciowego występują rzadko, co wpływa na opóźnienie rozpoznania, a także rokowanie pacjentów [1]. Do najbardziej rozpowszechnionych należą NAM i NASCC. We wcześniej przeprowadzonym w Polsce badaniu Sobjanek i wsp. wykazali, że NAM i NASCC stanowią odpo- 
Table I. Characteristics of patients

\begin{tabular}{|c|c|c|c|c|c|c|c|}
\hline \multirow[t]{2}{*}{ Parameter } & \multicolumn{7}{|c|}{ Patient } \\
\hline & I & 2 & 3 & 4 & 5 & 6 & 7 \\
\hline Diagnosis & NAM & NAM & NAM & NASCC & NASCC & NASCC & NASCC \\
\hline Gender & Male & Female & Female & Male & Female & Male & Male \\
\hline Age & 84 & 33 & 56 & 71 & 69 & 67 & 73 \\
\hline Phototype & II & III & III & III & $\|$ & $\|$ & III \\
\hline $\begin{array}{l}\text { Personal/ } \\
\text { familial skin } \\
\text { cancer history }\end{array}$ & - & - & - & - & - & - & - \\
\hline $\begin{array}{l}\text { Trauma } \\
\text { history }\end{array}$ & - & - & - & - & - & - & - \\
\hline Location & I RT & IV LF & I LT & IV RF & II LF & I RF & I RF \\
\hline $\begin{array}{l}\text { Clinical } \\
\text { features }\end{array}$ & $\begin{array}{l}\text { Amelanotic, } \\
\text { fast growing } \\
\text { tumour }\end{array}$ & $\begin{array}{l}\text { Longitudinal } \\
\text { melanonychia }\end{array}$ & $\begin{array}{l}\text { Irregular } \\
\text { pigmented } \\
\text { subungual } \\
\text { macule, } \\
\text { yellowish } \\
\text { discolouration } \\
\text { of the nail plate }\end{array}$ & $\begin{array}{c}\text { Hyperkeratotic } \\
\text { tumour, } \\
\text { nail plate } \\
\text { destruction }\end{array}$ & $\begin{array}{c}\text { Subungual } \\
\text { hyperkeratotic } \\
\text { tumour }\end{array}$ & $\begin{array}{l}\text { Ulcerated } \\
\text { tumour, } \\
\text { nail plate } \\
\text { destruct- } \\
\quad \text { ion }\end{array}$ & $\begin{array}{l}\text { Exophytic } \\
\text { crusted } \\
\text { tumour } \\
\text { with nail } \\
\text { plate } \\
\text { destruction } \\
\text { and bone } \\
\text { infiltration }\end{array}$ \\
\hline $\begin{array}{l}\text { Dermoscopic } \\
\text { features }\end{array}$ & $\begin{array}{l}\text { White-pinkish } \\
\text { structureless } \\
\text { areas, "sticky } \\
\text { fiber sign" }\end{array}$ & $\begin{array}{l}\text { Heterogeneity } \\
\text { in colour and } \\
\text { irregularity of } \\
\text { thickness and } \\
\text { parallelism of the } \\
\text { longitudinal lines }\end{array}$ & $\begin{array}{l}\text { Brown-grey } \\
\text { structureless } \\
\text { area, dystrophy } \\
\text { of the distal } \\
\text { portion of the } \\
\text { nail plate along } \\
\text { with its yellowish } \\
\text { discolouration }\end{array}$ & $\begin{array}{c}\text { Polymorphic } \\
\text { blood vessels } \\
\text { on the } \\
\text { white-pinkish } \\
\text { background, } \\
\text { "sticky fiber } \\
\text { sign" }\end{array}$ & $\begin{array}{c}\text { White-purplish } \\
\text { discolouration of the } \\
\text { nail plate, irregular } \\
\text { border of the distal } \\
\text { part of the nail } \\
\text { plate, red-yellowish } \\
\text { structureless areas in } \\
\text { the distal part of the } \\
\text { nail bed }\end{array}$ & - & - \\
\hline Histology & $\begin{array}{c}\text { Excisional } \\
\text { biopsy: } \\
\text { nodular } \\
\text { melanoma } \\
\text { (Breslow } \\
4.2 \mathrm{~mm} \text {, } \\
\text { mitotic rate } \\
19 / \mathrm{mm}^{2} \\
\text { ulceration }+ \text { ) }\end{array}$ & $\begin{array}{l}\text { Excisional biopsy } \\
\text { of nail matrix } \\
\text { pigmented } \\
\text { macule } \\
\text { (performed } \\
\text { after nail plate } \\
\text { avulsion): } \\
\text { melanoma in situ }\end{array}$ & $\begin{array}{l}\text { Excisional biopsy } \\
\text { of the nail bed } \\
\text { pigmented } \\
\text { macule } \\
\text { (performed after } \\
\text { surgical removal } \\
\text { of the nail plate): } \\
\text { melanoma in situ }\end{array}$ & $\begin{array}{c}\text { Tumour } \\
\text { biopsy: } \\
\text { squamous cell } \\
\text { carcinoma } \\
\text { in situ }\end{array}$ & $\begin{array}{l}\text { Excisional biopsy } \\
\text { (performed after } \\
\text { surgical removal } \\
\text { of the nail plate): } \\
\text { squamous cell } \\
\text { carcinoma in situ }\end{array}$ & $\begin{array}{c}\text { Invasive } \\
\text { squamous } \\
\text { cell } \\
\text { carcinoma }\end{array}$ & $\begin{array}{c}\text { Invasive } \\
\text { squamous } \\
\text { cell } \\
\text { carcinoma }\end{array}$ \\
\hline TNM & T4bNOMO & TisNOMO & TisNOMO & TisNOMO & TisNOMO & TINOMO & T3NOMO \\
\hline Bone invasion & - & - & - & - & - & - & + \\
\hline Treatment & $\begin{array}{l}\text { Amputation of } \\
\text { the first right } \\
\text { toe; sentinel } \\
\text { lymph node } \\
\text { biopsy was } \\
\text { unsuccessful } \\
\text { due to lack of } \\
\text { isotope spread }\end{array}$ & $\begin{array}{l}\text { Amputation of } \\
\text { distal phalanx of } \\
\text { IV left fingernail }\end{array}$ & $\begin{array}{l}\text { Amputation of } \\
\text { distal phalanx of } \\
\text { first left toe }\end{array}$ & $\begin{array}{c}\text { Topical } \\
\text { treatment with } \\
\text { 5-fluorouracil } \\
\text { (twice daily, } \\
12 \text { weeks) }\end{array}$ & $\begin{array}{l}\text { Wide excision, partial- } \\
\text { dermal skin graft }\end{array}$ & $\begin{array}{c}\text { Wide } \\
\text { excision, } \\
\text { partial- } \\
\text { dermal } \\
\text { skin graft }\end{array}$ & $\begin{array}{c}\text { Amputation } \\
\text { of distal } \\
\text { phalanx }\end{array}$ \\
\hline
\end{tabular}

NAM - nail apparatus melanoma, NASCC - nail apparatus squamous cell carcinoma, + presence, - absence, RF - right fingernail, LF - left fingernail, $R T$ - right toenail, $L T$ - left toenail 
Tabela I. Charakterystyka pacjentów

\begin{tabular}{|c|c|c|c|c|c|c|c|}
\hline \multirow[t]{2}{*}{ Zmienna } & \multicolumn{7}{|c|}{ Pacjent } \\
\hline & I & 2 & 3 & 4 & 5 & 6 & 7 \\
\hline Rozpoznanie & NAM & NAM & NAM & NASCC & NASCC & NASCC & NASCC \\
\hline Płeć & Mężczyzna & Kobieta & Kobieta & Mężczyzna & Kobieta & Mężczyzna & Mężczyzna \\
\hline Wiek & 84 & 33 & 56 & 71 & 69 & 67 & 73 \\
\hline Fototyp skóry & II & III & III & III & $\|$ & II & III \\
\hline $\begin{array}{l}\text { Wywiad } \\
\text { osobniczy } \\
\text { lub rodzinny } \\
\text { w kierunku } \\
\text { raka skóry }\end{array}$ & - & - & - & - & - & - & - \\
\hline $\begin{array}{l}\text { Uraz } \\
\text { w wywiadzie }\end{array}$ & - & - & - & - & - & - & - \\
\hline Lokalizacja & $\begin{array}{c}\text { Palec I } \\
\text { stopy prawej }\end{array}$ & $\begin{array}{l}\text { Palec IV } \\
\text { ręki lewej }\end{array}$ & $\begin{array}{c}\text { Palec I } \\
\text { stopy lewej }\end{array}$ & $\begin{array}{c}\text { Palec IV } \\
\text { ręki prawej }\end{array}$ & $\begin{array}{c}\text { Palec II } \\
\text { ręki lewej }\end{array}$ & $\begin{array}{c}\text { Palec I } \\
\text { ręki prawej }\end{array}$ & $\begin{array}{c}\text { Palec I } \\
\text { ręki prawej }\end{array}$ \\
\hline Cechy kliniczne & $\begin{array}{c}\text { Amelanotyczny, } \\
\text { szybko rosnący } \\
\text { guz }\end{array}$ & $\begin{array}{c}\text { Melanonychia } \\
\text { podłużna }\end{array}$ & $\begin{array}{c}\text { Podpaznokciowa } \\
\text { plama } \\
\text { barwnikowa } \\
\text { o nieregularnym } \\
\text { kształcie, żółte } \\
\text { przebarwienie } \\
\text { płytki } \\
\text { paznokciowej }\end{array}$ & $\begin{array}{l}\text { Hiperkeratotyczny } \\
\text { guz, dystrofia płytki } \\
\text { paznokciowej }\end{array}$ & $\begin{array}{c}\text { Hiperkeratotyczny } \\
\text { guz } \\
\text { podpaznokciowy }\end{array}$ & $\begin{array}{l}\text { Owrzodziały } \\
\text { guz, } \\
\text { destrukcja } \\
\text { płytki } \\
\text { paznokciowej }\end{array}$ & $\begin{array}{c}\text { Egzofityczny, } \\
\text { pokryty } \\
\text { strupem guz } \\
\text { z destrukcją } \\
\text { płytki } \\
\text { paznokciowej } \\
\text { i zajęciem kości }\end{array}$ \\
\hline $\begin{array}{l}\text { Cechy } \\
\text { dermoskopowe }\end{array}$ & $\begin{array}{c}\text { Biało-różowe } \\
\text { obszary } \\
\text { bezstrukturalne } \\
\text { i objaw } \\
\text { „przyklejonego } \\
\text { włókna” }\end{array}$ & $\begin{array}{c}\text { Niejednorodność } \\
\text { barwy linii } \\
\text { równoległych } \\
\text { i nieregularność } \\
\text { pod względem } \\
\text { grubości } \\
\text { i odległości } \\
\text { między nimi }\end{array}$ & $\begin{array}{c}\text { Brązowo- } \\
\text { szary obszar } \\
\text { bezstrukturalny, } \\
\text { dystrofia } \\
\text { oraz żółtawe } \\
\text { przebarwienie } \\
\text { dystalnej } \\
\text { części płytki } \\
\text { paznokciowej }\end{array}$ & $\begin{array}{c}\text { Naczynia } \\
\text { polimorficzne na } \\
\text { biało-różowym } \\
\text { tle, objaw } \\
\text { „przyklejonego } \\
\text { włókna” }\end{array}$ & $\begin{array}{l}\text { Biało-fioletowe } \\
\text { przebarwienie } \\
\text { płytki paznokcia, } \\
\text { nieregularny } \\
\text { brzeg dystalnego } \\
\text { końca płytki } \\
\text { paznokciowej, } \\
\text { czerwono- } \\
\text {-żółte obszary } \\
\text { bezstrukturalne } \\
\text { w dystalnej } \\
\text { części łożyska } \\
\text { paznokcia }\end{array}$ & - & - \\
\hline Histologia & $\begin{array}{c}\text { Biopsja } \\
\text { wycinająca: } \\
\text { czerniak guzkowy } \\
(4,2 \text { mm grubości } \\
\text { wg Breslowa, } \\
\text { wskaźnik } \\
\text { mitotyczny } \\
\text { I9/mm², } \\
\text { owrzodzenie }+ \text { ) }\end{array}$ & $\begin{array}{c}\text { Biopsja } \\
\text { wycinająca plamy } \\
\text { barwnikowej } \\
\text { w obrębie } \\
\text { macierzy } \\
\text { paznokcia (po } \\
\text { chirurgicznym } \\
\text { zdjęciu płytki } \\
\text { paznokciowej): } \\
\text { czerniak in situ }\end{array}$ & $\begin{array}{c}\text { Biopsja } \\
\text { wycinająca plamy } \\
\text { barwnikowej } \\
\text { w obrębie } \\
\text { łożyska (po } \\
\text { chirurgicznym } \\
\text { zdjęciu płytki } \\
\text { paznokciowej): } \\
\text { czerniak in situ }\end{array}$ & $\begin{array}{l}\text { Biopsja guza: } \\
\text { rak kolczysto- } \\
\text { komórkowy } \\
\text { in situ }\end{array}$ & $\begin{array}{c}\text { Biopsja } \\
\text { wycinająca (po } \\
\text { chirurgicznym } \\
\text { zdjęciu płytki } \\
\text { paznokciowej): } \\
\text { rak kolczysto- } \\
\text { komórkowy } \\
\text { in situ }\end{array}$ & $\begin{array}{c}\text { Inwazyjny } \\
\text { rak } \\
\text { kolczysto- } \\
\text { komórkowy }\end{array}$ & $\begin{array}{l}\text { Inwazyjny rak } \\
\text { kolczysto- } \\
\text { komórkowy }\end{array}$ \\
\hline TNM & T4bNOMO & TisNOMO & TisNOMO & TisNOMO & TisNOMO & TINOMO & T3NOMO \\
\hline $\begin{array}{l}\text { Naciek struktur } \\
\text { kostnych }\end{array}$ & - & - & - & - & - & - & + \\
\hline Leczenie & $\begin{array}{l}\text { Amputacja palca } \\
\text { I stopy prawej; } \\
\text { biopsja węzła } \\
\text { wartowniczego } \\
\text { zakończona } \\
\text { niepowodzeniem } \\
\text { ze względu } \\
\text { na brak } \\
\text { przemieszczenia } \\
\text { izotopu }\end{array}$ & $\begin{array}{l}\text { Amputacja palca } \\
\text { IV ręki lewej na } \\
\text { poziomie paliczka } \\
\text { dystalnego }\end{array}$ & $\begin{array}{c}\text { Amputacja } \\
\text { palca I } \\
\text { stopy lewej na } \\
\text { poziomie paliczka } \\
\text { dystalnego }\end{array}$ & $\begin{array}{c}\text { Leczenie } \\
\text { miejscowe } \\
\text { 5-fluorouracylem } \\
\text { (2 razy dziennie } \\
\text { przez } 12 \text { tygodni) }\end{array}$ & $\begin{array}{c}\text { Szerokie } \\
\text { wycięcie, } \\
\text { przeszczep } \\
\text { skóry pośredniej } \\
\text { grubości }\end{array}$ & $\begin{array}{c}\text { Szerokie } \\
\text { wycięcie, } \\
\text { przeszczep } \\
\text { skóry } \\
\text { pośredniej } \\
\text { grubości }\end{array}$ & $\begin{array}{c}\text { Amputacja } \\
\text { na poziomie } \\
\text { paliczka } \\
\text { dystalnego }\end{array}$ \\
\hline
\end{tabular}

NAM - czerniak aparatu paznokciowego, NASCC - rak kolczystokomórkowy aparatu paznokciowego, + obecność, - brak. 


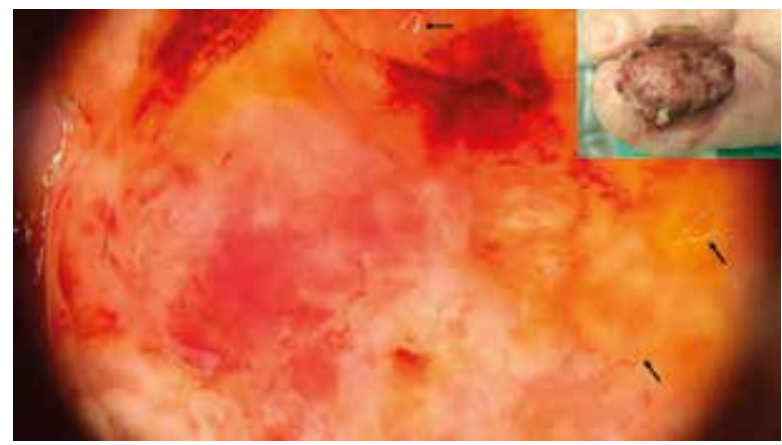

Figure I. Patient I. Clinical presentation: amelanotic melanoma presenting as an ulcerated tumour of the nail apparatus of the first right toe. Dermoscopy shows white-pink structureless areas within the tumour mass. The red-yellowish structureless areas correspond with the presence of serohaemorrhagic crust

Rycina I. Pacjent I. Obraz kliniczny: czerniak amelanotyczny w postaci owrzodzialego guza w obrębie aparatu paznokciowego palca I stopy prawej. W obrazie dermoskopowym w masie guza widoczne są biało-różowe obszary bezstrukturalne. Czerwono-żółte obszary bezstrukturalne odpowiadają obecności krwisto-surowiczego strupa
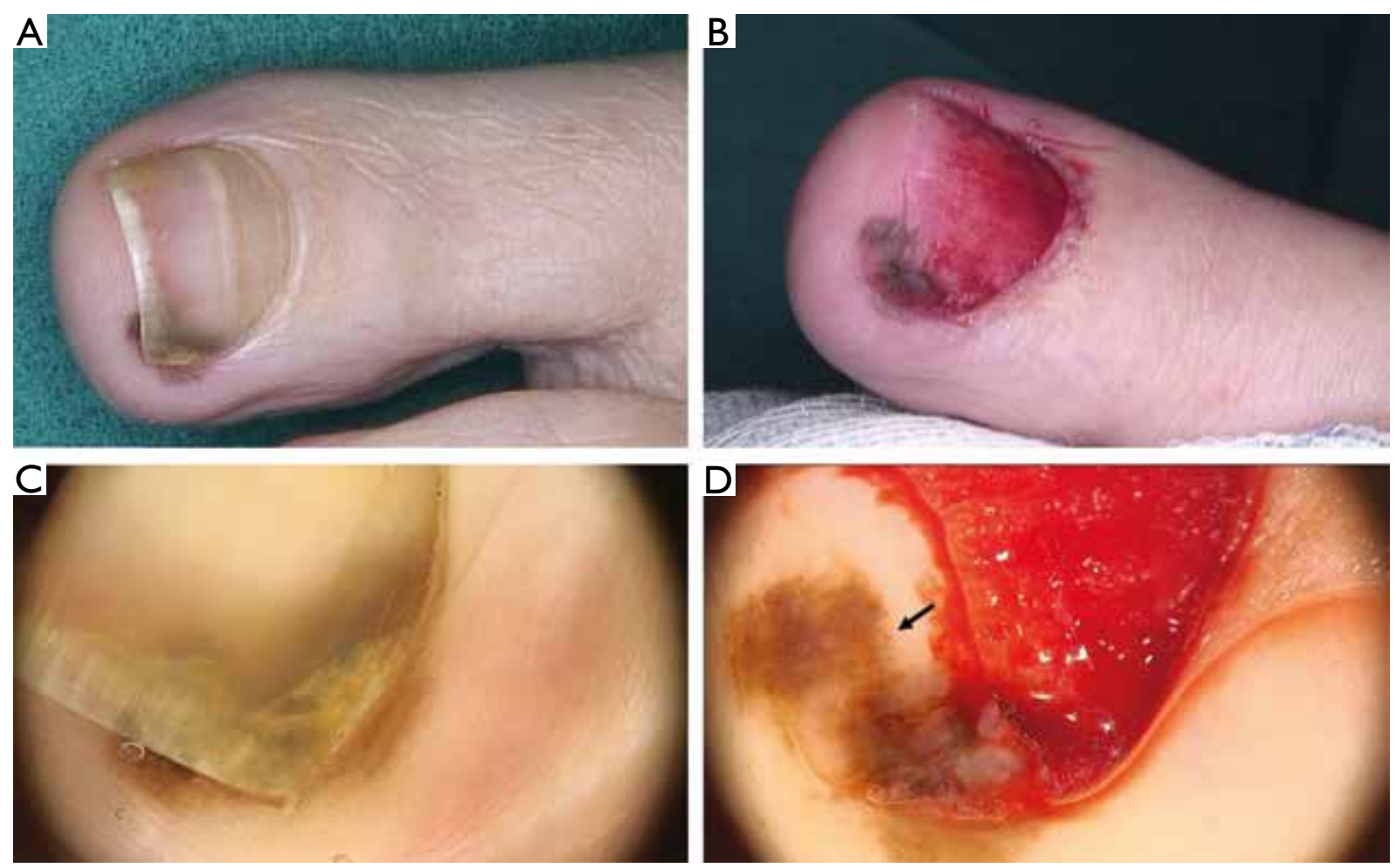

Figure 3. Patient 3. Nail apparatus melanoma. Clinical presentation before (A) and after (B) surgical nail plate avulsion: irregular, poorly demarcated, pigmented macule of the nail bed of the first left toe. Dermoscopic presentation before (C) and after (D) surgical nail plate avulsion. Nail plate dermoscopy shows irregular brown-grey structureless area and dystrophy of the distal portion of the nail plate along with its yellowish discolouration. There is no evidence of LM. Intraoperative dermoscopy shows: asymmetry of the colour and structures, the presence of the gray structureless areas, pseudopods in the medial part of the lesion (arrow)

Rycina 3. Pacjent 3. Czerniak aparatu paznokciowego. Obraz kliniczny przed chirurgicznym usunięciem płytki paznokciowej (A) i po usunięciu (B): niewyraźnie odgraniczona plama barwnikowa o nieregularnym kształcie w obrębie łożyska paznokcia palca I stopy lewej. Obraz dermoskopowy przed chirurgicznym usunięciem płytki paznokciowej (C) i po usunięciu (D). W dermoskopii wykonanej przez powierzchnię płytki paznokciowej widoczny jest nieregularny, brązowo-szary obszar bezstrukturalny, dystrofia oraz żółtawe przebarwienie dystalnej części płytki paznokciowej. Brak cech melanonychii podłużnej. W dermoskopii śródoperacyjnej widoczna jest asymetria barwy i struktur, szare obszary bezstrukturalne oraz pseudopodia w przyśrodkowej części zmiany (zaznaczone strzałką) 


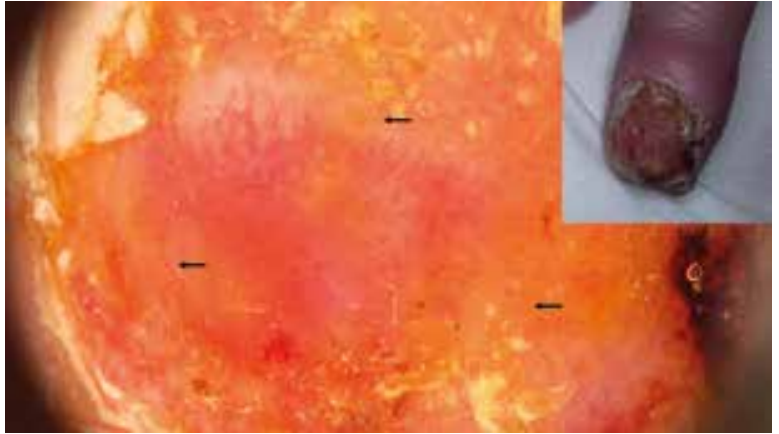

one case of atypical melanocytic hyperplasia in a 12-year-old boy was diagnosed (unpublished data).

Nail apparatus melanoma originates from the melanocytes of the nail apparatus. The clinical presentation and prognosis of the NAM depends on the tumour origin. $38-76 \%$ of NAMs originate from the nail matrix and present initially as longitudinal melanonychia (LM) (defined as a longitudinal hyperpigmented band that extends from the matrix to the distal end of the nail plate). Subsequent progression of the tumour may be associated with nail mass and nail plate dystrophy and periungual pigmentation. Nail apparatus melanoma initially presenting as periungual pigmentation or a nail bed pathological mass without the LM originates from periungual or nail bed melanocytes, respectively. Nail apparatus melanoma that develops from LM seems to have a longer radial growth phase, a more indolent course and a better prognosis [4].

Dermoscopic evaluation of LM improves the diagnostic accuracy of NAM. The width of the pigmented band higher than $2 / 3$ of the nail plate, the presence of grey or black colour, the irregularity of the thickness, colour and parallelism of the longitudinal lines, the presence of micro-Hutchinson sign (pigmentation of the cuticle visible on dermoscopy but not with the naked eye) and granular pigmentation are considered suspicious features [5].

Nevertheless, during dermoscopic assessment of an adult patient with LM the most important factor is the clinical context. Every case of adult-onset LM should be treated with caution, as nail apparatus melanoma in situ (NAMis) may initially reveal benign clinical and dermoscopic presentation [6]. In such cases dermoscopy cannot replace the histopathological examination.

Dermoscopy is also helpful in the initial assessment of pink tumours of the nail apparatus, as it allows detection of clinically invisible remnants of pigment in most hypomelanotic NAMis. Other clues to NAM are milky-red areas and polymorphic vascular pattern, especially in the presence of dotted vessels, hairpin vessels and linear irregular vessels [7].
Figure 4. Patient 4. Nail apparatus squamous cell carcinoma in situ. Clinical presentation: hyperkeratotic tumour of the nail apparatus of the fourth right finger. Dermoscopy shows: polymorphic blood vessels on the white-pinkish background, the presence of "sticky fibers" - evidence of ulceration; on the periphery white-yellowish structureless areas corresponding to hyperkeratotic masses are visualized

Rycina 4. Pacjent 4. Rak kolczystokomórkowy aparatu paznokciowego in situ. Obraz kliniczny: hiperkeratotyczny guz aparatu paznokciowego palca IV ręki prawej. W obrazie dermoskopowym widoczne są naczynia polimorficzne na biało-różowym tle oraz objaw „przyklejonego włókna” związany z obecnością owrzodzenia; na obwodzie zmiany widać biało-żółtawe obszary bezstrukturalne odpowiadające obecności mas hiperkeratotycznych

wiednio 6,2\% i 2,3\% wszystkich guzów aparatu paznokciowego [2]. Ten sam autor w 2012 r. analizował zmiany w obrębie aparatu paznokciowego w populacji pediatrycznej $(n=82)$, nie stwierdzając nowotworów złośliwych [3]. Choć według doniesień występowanie nowotworów złośliwych aparatu paznokciowegou dzieci w populacji kaukaskiej jest rzadkie, w 2017 r. w gdańskiej Klinice Dermatologii rozpoznano przypadek atypowej hiperplazji melanocytów u 12-letniego chłopca (dane niepublikowane).

Czerniak aparatu paznokciowego wywodzi się z melanocytów aparatu paznokciowego. Obraz kliniczny i rokowanie w NAM zależą od punktu wyjścia tego nowotworu. W 38-76\% przypadków NAM rozwija się w macierzy paznokcia, prezentując się początkowo jako melanonychia podłużna (MP) (podłużne przebarwienie przebiegające od macierzy paznokcia aż po dystalny koniec płytki paznokciowej). Progresja guza może wiązać się ze wzrostem patologicznej masy w obrębie aparatu paznokciowego, dystrofią płytki paznokciowej i pigmentacją okołopaznokciową. Czerniak aparatu paznokciowego prezentujący się od początku jako pigmentacja okołopaznokciowa lub patologiczna masa łożyska paznokcia, bez towarzyszącejMP, wywodzi sięodpowiednio z melanocytów okołopaznokciowych lub łożyskowych. Wydaje się, że NAM manifestujące się początkowo jako MP cechują się dłuższą fazą wzrostu radialnego, powolniejszą progresją i lepszym rokowaniem [4].

Ocena dermoskopowa MP ułatwia diagnostykę NAM. Za cechy podejrzane uznaje się obecność przebarwionego prążka o szerokości przekraczającej 2/3 płytki paznokciowej, obecność koloru szarego lub czarnego, nieregularną grubość, barwę i nierównoległy przebieg podłużnych linii, występowanie mikroobjawu Hutchinsona (tj. przebarwienia obrąbka naskórkowego niewidocznego gołym okiem, lecz stwierdzanego dermoskopowo) oraz pigmentacji o charakterze ziarnistym [5].

Niezależnie od tego przy ocenie dermoskopowej dorosłych pacjentów z MP kluczowe znaczenie ma kontekst kliniczny. Każdy przypadek MP u osoby dorosłej wymaga ostrożnego podejścia, ponieważ czerniak aparatu paznokciowego in situ (NAMis) może początkowo nie wykazywać cech podejrzanych klinicznie i dermo- 

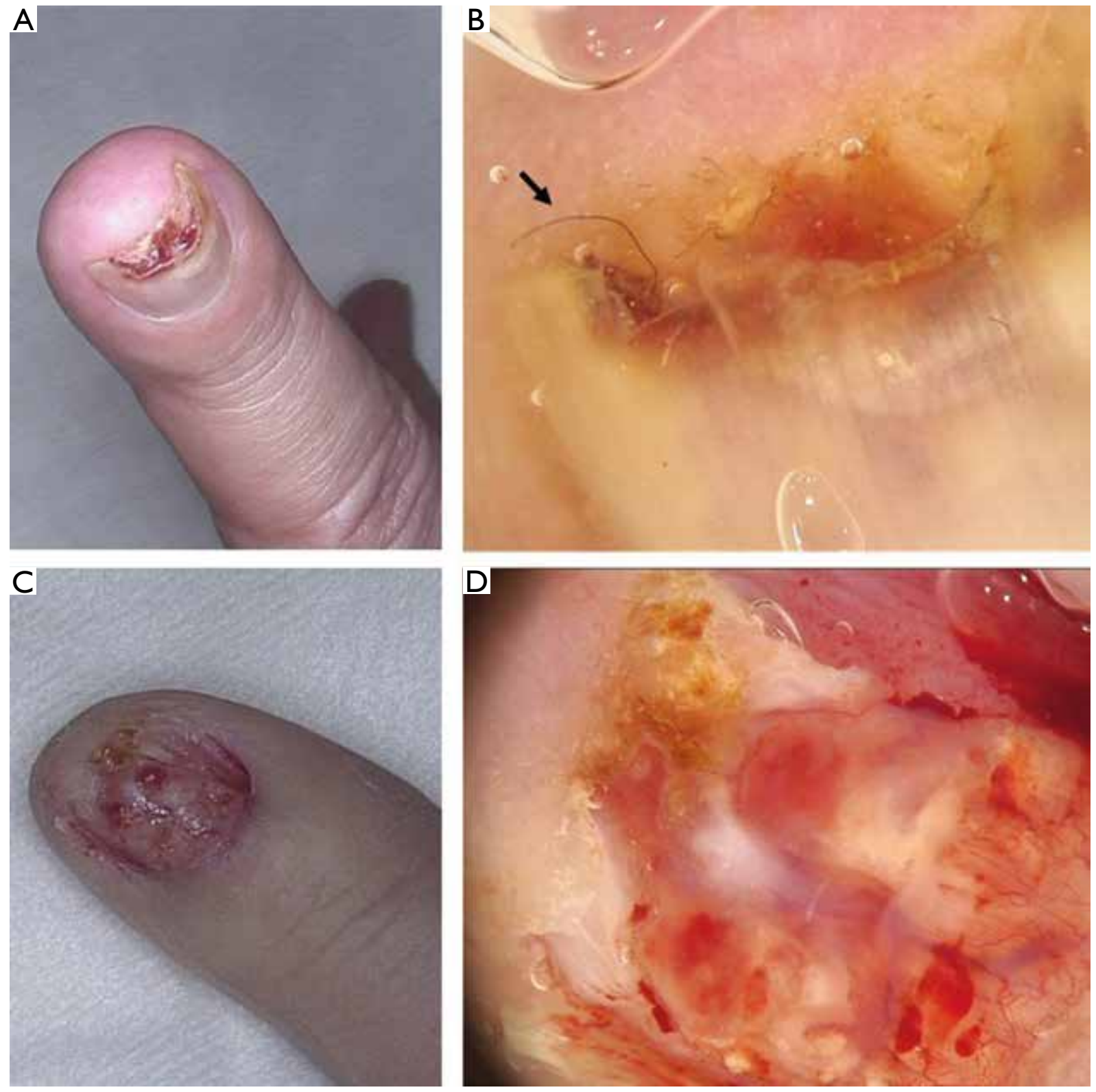

Figure 5. Patient 5. Nail apparatus squamous cell carcinoma in situ. Clinical and dermoscopic presentation before and after surgical nail plate avulsion. A - Subungual, hyperkeratotic tumour of the second left finger associated with secondary onycholysis and leukonychia. C - Surgical avulsion of the nail plate revealed the extension of the pathological mass. Dermoscopic presentation before (B) and after (D) surgical nail plate avulsion. B - Nail plate dermoscopy shows irregular white-grey structureless area of the central portion of the nail plate, irregular border of the distal part of the nail plate and red-yellowish structureless areas in the distal part of the nail bed. D - Intraoperative dermoscopy shows the presence of structureless areas of white, pink and red colour as well as the presence of polymorphic blood vessels

Rycina 5. Pacjent 5. Rak kolczystokomórkowy aparatu paznokciowego in situ. Obraz kliniczny i dermoskopowy przed chirurgicznym usunięciem płytki paznokciowej i po usunięciu. A - Podpaznokciowy, hiperkeratotyczny guz palca II ręki lewej z towarzyszącą onycholizą oraz leukonychią. C - Zasięg masy patologicznej widoczny po chirurgicznym usunięciu płytki paznokciowej. Obraz dermoskopowy przed chirurgicznym usunięciem płytki paznokciowej (B) i po usunięciu (D). B - W dermoskopii wykonanej przez powierzchnię płytki paznokciowej widoczny jest nieregularny, biało-szary obszar bezstrukturalny w środkowej części płytki paznokciowej, nieregularny brzeg dystalnego końca płytki paznokciowej oraz czerwono-żótte obszary bezstrukturalne w dystalnej części łożyska paznokcia. D - W dermoskopii śródoperacyjnej obecne obszary bezstrukturalne barwy białej, różowej i czerwonej oraz naczynia polimorficzne

The management of NAM is controversial, as no treatment guidelines have been created so far. The results of several studies have not shown higher survival rates in patients treated with aggressive amputation. The recent literature approach suggests skopowo [6]. W takich przypadkach dermoskopia nie może zastąpić badania histopatologicznego.

Badanie dermoskopowe jest także przydatne przy wstępnej ocenie bezbarwnikowych (różowych) guzów aparatu paznokciowego, co umożliwia identyfikację 


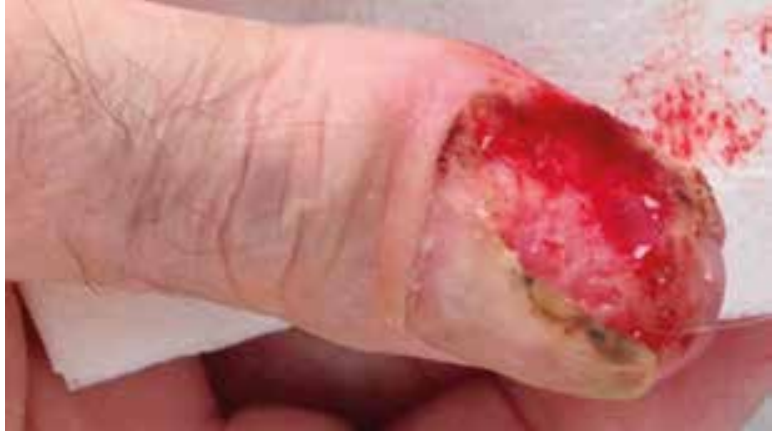

Figure 6. Invasive nail apparatus squamous cell carcinoma presenting as the ulcerated tumour with nail plate destruction

Rycina 6. Obraz kliniczny inwazyjnego raka kolczystokomórkowego aparatu paznokciowego - owrzodziały guz z destrukcją płytki paznokciowej

excision of the nail apparatus ("functional" excision) as a treatment option of NAMis and more distal amputation for invasive NAM [8]. In our department the decision concerning the final treatment method (amputation vs. functional excision of nail apparatus) is based on a consensus between the dermatologist, histopathologist, oncological surgeon and the patients.

The clinical presentation of NASCC also depends on the location of the neoplastic process. Periungual squamous cell carcinoma manifests as a hyperkeratotic mass, fibrokeratoma-like tumour, erosion, scaling, fissuring and swelling. Subungual involvement may present as onycholysis, ulceration, subungual tumour, erythronychia, leukonychia and melanonychia. A common but under-recognized sign of NASCC seems to be oozing $[9,10]$.

Nail apparatus squamous cell carcinoma is most commonly misdiagnosed as a viral wart, but also as onychomycosis, post-traumatic dystrophy, eczema, paronychia, subungual exostosis, subungual keratoacanthoma, fibrokeratoma, onychopapilloma, onychomatricoma and melanoma [10]. A biopsy of the suspicious lesion is mandatory to avoid such diagnostic pitfalls. In our department in suspicious cases the biopsy is made after nail plate avulsion.

The role of dermoscopy in the diagnosis of NASCC is poorly investigated [11]. Teysseire et al., who analysed dermoscopic criteria of 44 cases of NASCC, concluded that frequent dermoscopic features were: irregular and unparalleled borders, hyperkeratosis underneath the nail plate, splinter haemorrhages and white longitudinal lines. However, the mentioned study also showed that the clinical and dermoscopic spectrum of NASCC may overlap with other tumours of the nail apparatus such as onychomatricoma and onychopapilloma - this problem requires further investigations [12, 13]. Giacomel et al. described a case illustrating the potential usefulness

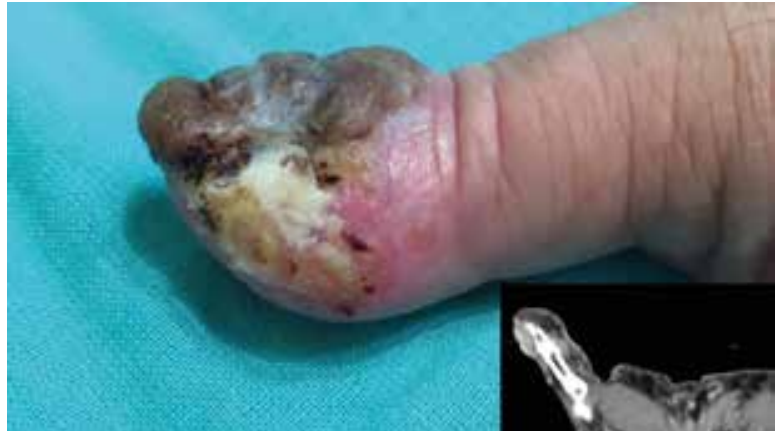

Figure 7. Advanced nail apparatus squamous cell carcinoma presenting as exophytic crusted tumour with nail plate destruction and bone infiltration

Rycina 7. Obraz kliniczny zaawansowanego raka kolczystokomórkowego aparatu paznokciowego - egzofityczny, pokryty strupem guz z destrukcją płytki paznokciowej i naciekiem struktur kostnych

klinicznie niedostrzegalnych depozytów barwnika w większości hipomelanotycznych NAM. Inne cechy wskazujące na NAM to obszary bezstrukturalne barwy mleczno-czerwonej oraz obecność polimorficznego wzorca naczyniowego, zwłaszcza ze współwystępowaniem naczyń w kształcie kropek, pętli oraz naczyń linijnych o nieregularnym przebiegu [7].

Postępowanie w przypadkach NAM jest kontrowersyjne, ponieważ nie opracowano dotąd wytycznych dotyczących leczenia. Wyniki uzyskane w kilku badaniach nie wykazały wyższego wskaźnika przeżycia u pacjentów leczonych metodą radykalnej amputacji. Według aktualnego piśmiennictwa zaleca się wycięcie aparatu paznokciowego (wycięcie „funkcjonalne”) jako opcję terapeutyczną u pacjentów z NAMis oraz bardziej dystalną amputację w przypadkach inwazyjnego NAM [8]. W gdańskiej Klinice Dermatologii ostateczną decyzję o metodzie leczenia (amputacja lub wycięcie „funkcjonalne" aparatu paznokciowego) podejmowano na podstawie konsensusu między dermatologiem, histopatologiem, chirurgiem onkologicznym i pacjentami.

Obraz kliniczny NASCC zależy również od umiejscowienia procesu nowotworowego. Rak kolczystokomórkowy w lokalizacji okołopaznokciowej ma postać masy hiperkeratotycznej, guza przypominającego włókniakorogowca, postać nadżerki, obszaru z obecnością złuszczania się, rozpadlin lub obrzęku. Z podpaznokciowym umiejscowieniem guza wiąże się obecność onycholizy, owrzodzenia, masy podpaznokciowej, erytronychii, leukonychii, melanonychii. Powszechnie występującym, choć niedocenianym, objawem NASCC wydaje się również obecność wysięku $[9,10]$.

Rak kolczystokomórkowy aparatu paznokciowego jest najczęściej błędnie rozpoznawany jako brodawka wirusowa, ale także jako grzybica paznokci, dystrofia pourazowa, wyprysk, zanokcica, podpaznokciowa wyrośl kostna, podpaznokciowy rogowiak kolczystokomórkowy, włókniakorogowiec, onychopapilloma, onychomatricoma i czerniak [10]. Badanie histopato- 
of dermoscopy in the diagnosis of periungual squamous cell carcinoma in situ. The authors described the presence of diffusely distributed dotted vessels and hyperkeratotic, targetoid structures [14].

We have found only one case report indicating the role of intraoperative dermoscopy in the diagnosis and treatment of NASCC [15]. The authors claimed that the presence of white structureless areas, polymorphous vascular pattern, yellow dots and scales favoured the diagnosis of subungual invasive squamous cell carcinoma.

Recommended first-line treatment in NASCC in situ is surgical resection. Nevertheless, due to the slow evolution and low metastatic potential other non-surgical approaches have been reported in the literature including topical imiquimod [16], topical fluorouracil [17] and photodynamic therapy [18, 19]. The presence of bone invasion (present in 18-60\% of cases) is an indication for amputation [10].

In the present case series we decided to recommend topical treatment with 5-fluorouracil in patient 4 due to the numerous internal comorbidities and the need for continuous anticoagulant therapy. Prior to the treatment the patient was asked to apply a keratolytic agent ( $30 \%$ urea cream, nightly) for 7 days to remove the hyperkeratotic masses and to improve the further fluorouracil penetration. The drug was applied twice daily for 12 weeks. The main disadvantage of the treatment in the patient's opinion was the presence of excessive oozing during the first weeks of therapy.

\section{CONCLUSIONS}

According to our material, nail apparatus malignancy is not uncommon, and it should be taken into account in the differential diagnosis of nail apparatus disorders. Dermoscopy is an important adjunct to the clinical differentiation between benign and malignant disorders of nail apparatus, but should always be interpreted together with the medical history and physical examination. Histopathological examination remains the gold standard in diagnosis of malignant tumours of the nail unit.

\section{CONFLICT OF INTEREST}

The authors declare no conflict of interest. logiczne jest niezbędne, aby uniknąć podobnych błędów diagnostycznych. W gdańskiej Klinice Dermatologii w przypadkach patologii aparatu paznokciowego o niejednoznacznym obrazie klinicznym biopsja wykonywana jest po uprzednim zdjęciu płytki paznokciowej.

Rola dermoskopii w diagnostyce NASCC nie jest dokładnie określona [11]. Teysseire i wsp. podczas analizy obrazów dermoskopowych 44 przypadków NASCC często stwierdzali obecność zmiany o nieregularnych i niewyraźnych granicach, hiperkeratozę podpłytkową, linijne wybroczyny podpaznokciowe (objaw drzazgi), białe podłużne linie. Badanie wykazało jednak, że spektrum objawów klinicznych i dermoskopowych NASCC może pokrywać się ze spektrum innych nowotworów w tej lokalizacji, takich jak onychomatricoma i onychopapilloma. Zagadnienie to wymaga dalszych szczegółowych badań $[12,13]$.

Giacomel i wsp. opisali przypadek wskazujący na przydatność dermoskopii w diagnostyce okołopaznokciowego raka kolczystokomórkowego in situ. Autorzy opisali obecność rozproszonych naczyń w kształcie kropek oraz białych struktur hiperkeratotycznych przypominających kształtem tarczę strzelniczą [14].

Autorzy niniejszej pracy znaleźli tylko jeden opis przypadku wskazujący na rolę śródoperacyjnej dermoskopii w diagnostyce i leczeniu NASCC [15]. W artykule stwierdzono, że obecność białych obszarów bezstrukturalnych, polimorficznego wzorca naczyniowego, żółtych kropek oraz łuski świadczy o rozpoznaniu inwazyjnego podpaznokciowego raka kolczystokomórkowego.

Zalecanym postępowaniem pierwszego wyboru w NASCC in situ jest resekcja chirurgiczna. Ze względu na powolną progresję zmian i niski potencjał metastatyczny w piśmiennictwie opisywane są także alternatywne metody leczenia, takie jak terapia miejscowa imikwimodem [16], 5-fluorouracylem [17], terapia fotodynamiczna $[18,19]$. Naciek struktur kostnych $(18-60 \%$ przypadków) jest wskazaniem do amputacji [10].

W przedstawionej serii przypadków u jednego pacjenta (pacjent 4) postanowiono wdrożyć leczenie miejscowe 5-fluorouracylem z powodu licznych chorób współistniejących oraz konieczności ciągłego leczenia przeciwkrzepliwego. Przed rozpoczęciem terapii zalecono pacjentowi stosowanie środka keratolitycznego (kremu z 30\% mocznikiem) raz dziennie wieczorem przez 7 dni, aby usunać zrogowaciałe masy i poprawić późniejszą penetrację 5-fluorouracylu. Lek był stosowany 2 razy dziennie przez 12 tygodni. Główną niedogodnością związaną z leczeniem był miejscowy nasilony wysięk $\mathrm{w}$ pierwszych tygodniach terapii.

\section{WNIOSKI}

Powyższa analiza pokazuje, że złośliwe nowotwory aparatu paznokciowego nie są rzadkością i powinny być brane pod uwagę $\mathrm{w}$ diagnostyce różnicowej schorzeń 
występujących w tej lokalizacji. Badanie dermoskopowe jest pomocne we wstępnym różnicowaniu łagodnych i złośliwych zmian w obrębie aparatu paznokciowego, jednak jego wynik powinien być interpretowany w zestawieniu $\mathrm{z}$ danymi z wywiadu i badania przedmiotowego. Złotym standardem w diagnostyce nowotworów złośliwych aparatu paznokciowego pozostaje badanie histopatologiczne.

\section{KONFLIKT INTERESÓW}

Autorzy nie zgłaszają konfliktu interesów.

\section{References}

Piśmiennictwo

1. Domínguez-Cherit J., Chanussot-Deprez C., Maria-Sarti H., Fonte-Avalos V., Vega-Memije E., Luis-Montoya P.: Nail unit tumors: a study of 234 patients in the dermatology department of the "Dr Manuel Gea González" General Hospital in Mexico City. Dermatol Surg 2008, 34, 1363-1371.

2. Sobjanek M., Michajłowski I., Włodarkiewicz A., Roszkiewicz J.: Łagodne guzy aparatu paznokciowego w materiale Kliniki Dermatologii, Wenerologii i Alergologii Gdańskiego Uniwersytetu Medycznego. Przegl Dermatol 2011, 98, 477-482.

3. Sobjanek M., Michajłowski I., Konczalska M., Włodarkiewicz A., Roszkiewicz J.: Childhood nail alterations in Polish population. Acta Dermatovenerol Croat 2012, 20, 95-97.

4. Lee W.J., Lee J.H., Won C.H., Chang S.E., Choi J.H., Moon K.C., et al.: Nail apparatus melanoma: a comparative, clinicoprognostic study of the initial clinical and morphological characteristics of 49 patients. J Am Acad Dermatol 2015, 73, 213-220.

5. Benati E., Ribero S., Longo C., Piana S., Puig S., Carrera C., et al.: Clinical and dermoscopic clues to differentiate pigmented nail bands: an International Dermoscopy Society study. J Eur Acad Dermatol Venereol 2017, 31, 732-736.

6. Knackstedt T., Jellinek N.J.: Limitations and challenges of nail unit dermoscopy in longitudinal melanonychia. J Am Acad Dermatol 2017, 76, e71-e72.

7. Phan A., Dalle S., Touzet S., Ronger-Savlé S., Balme B., Thomas L.: Dermoscopic features of acral lentiginous melanoma in a large series of 110 cases in a white population. Br J Dermatol 2010, 162, 765-771.

8. Richert B.: Treatment of nail unit melanoma. [In:] Melanonychias. N. Di Chiacchio, A. Tosti (eds.), Springer, 2017, 141-150.

9. Sobjanek M., Michajłowski I., Malek M., Biernat W., Włodarkiewicz A., Roszkiewicz J.: Squamous cell carcinoma of the nail apparatus in the population of Northern Poland. Postep Derm Alergol 2012, 29, 148-151.

10. Lecerf P., Richert B., Theunis A., André J.: A retrospective study of squamous cell carcinoma of the nail unit diagnosed in a Belgian general hospital over a 15-year period. J Am Acad Dermatol 2013, 69, 253-261.

11. Teysseire S., Dalle S., Duru G., Phan A., Debarbieux S., Poulhalon N., et al.: Dermoscopic features of subungual squamous cell carcinoma: a study of 44 cases. Dermatology 2017, 233, 184-191.

12. Lesort C., Debarbieux S., Duru G., Dalle S., Poulhalon N., Thomas L.: Dermoscopic features of onychomatricoma: a study of 34 cases. Dermatology 2015, 231, 177-183.

13. Tosti A., Schneider S.L., Ramirez-Quizon M.N., Zaiac M., Miteva M.: Clinical, dermoscopic, and pathologic features of onychopapilloma: a review of 47 cases. J Am Acad Dermatol 2016, 74, 521-526.

14. Giacomel J., Lallas A., Zalaudek I., Argenziano G.: Periungual Bowen disease mimicking chronic paronychia and diagnosed by dermoscopy. J Am Acad Dermatol 2014, 71, e65-e67.

15. Göktay F., Aydıngöz İ.E., Güneş P.G., Atış G.: Intraoperative dermoscopic patterns of subungual squamous cell carcinoma: a case report. Australas J Dermatol 2017, 58, e243-e245.

16. Laffitte E., Saurat J.H.: Recurrent Bowen's disease of the nail: treatment by topical imiquimod (Aldara). Ann Dermatol Venereol 2003, 130, 211-213.

17. Sau P., McMarlin S.L., Sperling L.C., Katz R.: Bowen's disease of the nail bed and periungual area. A clinicopathologic analysis of seven cases. Arch Dermatol 1994, 130, 204-209.

18. Tan B., Sinclair R., Foley P.: Photodynamic therapy for subungual Bowen's disease. Australas J Dermatol 2004, 45, 172-174.

19. Usmani N., Stables G.I., Telfer N.R., Stringer M.R.: Subungual Bowen's disease treated by topical aminolevulinic acid-photodynamic therapy. J Am Acad Dermatol 2005, 53, 273-276.

Received: 9.04 .2018

Accepted: 12.06 .2018

Otrzymano: $9.04 .2018 \mathrm{r}$.

Zaakceptowano: $12.06 .2018 \mathrm{r}$.

How to cite this article

Romaszkiewicz A., Sławińska M., Biernat W., Drucis K., Nowicki R.J., Sobjanek M.: Malignancy of the nail apparatus - clinical and dermoscopic analysis. Dermatol Rev/Przegl Dermatol 2018, 105, 593-603. DOI: https://doi.org/10.5114/dr.2018.79171. 